\title{
Penerapan Layanan Bimbingan Kelompok dengan Menggunakan Permainan untuk Membantu Meningkatkan Penerimaan Diri Siswa
}

\author{
Arni Ulan' ${ }^{1}$ Idriani Idris ${ }^{2}$, Nurul Maulida Alwi ${ }^{3}$ \\ ${ }^{1}$ Sekolah Menengah Pertama Negeri 1 Tompobulu Kabupaten Bantaeng \\ ${ }^{2,3}$ Fakultas Ilmu Pendidikan Universitas Negeri Gorontalo
}

Email: Idrianiidris02@ung.ac.id

\begin{abstract}
ABSTRAK
Penelitian ini bertujuan untuk mengetahui penggunaan teknik permainan melalui bimbingan kelompok dalam meningkatkan penerimaan diri siswa kelas VII SMP Negeri 8 Makassar. Penelitian ini menggunakan pendekatan Kualitatif terhadap 10 subjek penelitian yang merupakan siswa kelas VII di SMP Negeri 8 Makassar. Pengumpulan data dengan menggunakan instrument observasi. Analisis data menggunakan deskriptif komparatif membandingkan kondisi awal dengan siklus kedua. Hasil penelitian menunjukkan bahwa ada peningkatan yang berarti signifikan yaitu penerapan teknik permainan dalam bimbingan kelompok dapat digunakan untuk meningkatkan penerimaan diri siswa kelas VII di SMP Negeri 8 Makassar. Hal ini terbukti dari keberhasilan siswa dalam mengikuti kegiatan bimbingan kelompok pada siklus pertama ke siklus kedua meningkat dari tinggi menjadi sangat tinggi dan dari kondisi awal dengan kategori sedang meningkat ke siklus 2 dengan kategori sangat tinggi .
\end{abstract}

Kata kunci :bimbingan kelompok; teknik permainan; penerimaan diri.

\begin{abstract}
This study aims to determine the use of simulation techniques through group guidance in increasing self-acceptance of VII grade students of SMP Negeri 8 Makassar. This study used a qualitative approach to 10 research subjects who were grade VII students at SMP Negeri 8 Makassar. Data collection using observation instruments. The data analysis used a comparative descriptive comparing the initial conditions with the second cycle. The results showed that there was a significant increase that the application of simulation techniques in group guidance can be used to increase self-acceptance of class VII students at SMP Negeri 8 Makassar. This increase can be seen in the results of observations. This is evident from the success of students in participating in group guidance activities in the first cycle to the second cycle increasing from high to very high and from the initial condition with the moderate category increasing to cycle 2 with the very high category.
\end{abstract}

Keywords: group guidance; simulation technique; self acceptance.

(C) 2021 Arni Ulan, Idriani Idris, Nurul Maulida Alwi

Under the license CC BY-SA 4.0

Pedagogika.fip@ung.ac.idＰ-ISSN: 2086-4469Ｅ-ISSN: 2716-0580 


\section{PENDAHULUAN}

Masa siswa merupakan masa transisi dari anak-anak ke dewasa. Periode ini dianggap sangat penting dalam kehidupan seseorang, khususnya dalam pembentukan identitas. Pembentukan identitas diri merupakan masalah krusial yang dihadapi terhadap perkembangan siswa. Wacana sosial memiliki pengaruh yang besar dalam pandangan dan penilaian seperti apa seharusnya dirinya. Proses internalisasi nilai-nilai sosial dan budaya yang dialami sacara nature maupun nurture melahirkan sistem standar penilaian diri ideal dalam lingkungan tersebut. Ketika individu menilai, memahami dan memandang dirinya secara riil sama dengan yang mereka idealkan maka siswa akan dengan mudah menerima dirinya. Sebaliknya, jika timbul kesenjangan yang besar antara diri ideal dengan pengalaman riil memungkinkan timbulnya permasalahan psikologis maupun perilaku maladatif. Ketidakmampuan individu dalam mengelola kesenjangan diri menunjukkan rendahnya penerimaan diri yaitu sikap positif terhadap diri sendiri mampu menerima keadaan kelebihan dan kekurangan diri sendiri, mampu menghargai diri sendiri dan menghargai orang lain serta mampu memahami keadaan emosionalnya sehingga tidak akan menjadi penghambat diri untuk berkembang secara optimal (Saifuddin, 2021; Sekali, 2020).

Sejalan dengan pendapat tersebut, Sitorus et al. (2019) mengatakan bahwa penerimaan diri merupakan ciri dari mental yang sehat dan sebagai karakteristik utama dalam meningkatkan aktualisasi diri. Hal ini menguatkan pendapat (Hurlock, 2013; Mualifah et al., 2019) mengatakan bahwa penerimaan diri berkaitan dengan penggambaran diri secara realistis antara kondisi dan harapan tanpa menerima batasan diri dengan melakukan penyesuaian sosial yang baik. Dengan demikian dapat dipahami bahwa penerimaan diri merupakan unsur penting yang perlu dimiliki untuk membentuk kondisi kesehatan mental dan kepribadian yang baik dan ketiadaannya dapat memberikan pengaruh pada kurang berkembangnya kepribadian yang diharapkan secara optimal. Hoffman, Lopez, \& Moats, Bernard (2013), memandang dari eksperimen dengan cara mediasi menyatakan bahwa penerimaan diri dapat membantu menjelaskan kepada diri sendiri mengenai hubungan antara perfeksionisme dan depresi yang ditentukan secara sosial, dan secara khusus dilapangan menunjukkan bahwa penerimaan diri yang rendah merupakan konsekuensi akibat dari keyakinan irasional siswa. Oleh karena itu 
dapat disimpulkan bahwa siswa yang dapat menerima dirinya akan cenderung baik hubungan sosialnya dikarenakan mampu menerima lingkungan teman sebayanya dengan baik pula. Penerimaan diri membantu siswa untuk mampu mengembangkan dirinya secara optimal, begitu pula sebaliknya, kurangnya penerimaan diri pada siswa menyebabkan mereka kesulitan dan tidak bisa mengembangkan diri.

Siswa yang mampu menerima dirinya melakukan evalusi diri positif dengan menunjukan rasa nyaman, peduli dan sadar akan karakteristiknya. Menyadari sisi positif negatifnya, dan tahu bagaimana hidup dengan sisi negatifnya. 9 aspek yang dapat dicantumkan untuk menjadi ukuran dalam tingkat penerimaan diri siswa yaitu mendengarkan dengan seksama apa yang sedang dijelaskan oleh pemimpin kelompok, mau menerima pendapat orang lain, mengemukakan pendapat/gagasan/ide, bertanya jika ada hal yang tidak dimengerti, melakukan permainan sesuai instruksi, dapat mengatur keadaan emosi, mampu bekerjasama dengan anggota kelompok, meneriman kritikan tanpa memusuhi serta mengemukakan manfaat permainan, Penerimaan diri penting untuk kesehatan mental, karena tidak adanya kemampuan untuk menerima diri sendiri dapat menyebabkan berbagai kesulitan-kesulitan emosional, termasuk kemarahan yang tidak terkontrol dan depresi (Hasmalawati, 2018).

Pada kenyataannya para siswa merasa sulit untuk menerima kondisi fisiknya, sebagian siswa merasa fisiknya tidak menarik, terlalu gemuk, terlalu kurus, dan memiliki warna kulit yang tidak dia sukai, dan kemudian tidak menerima kekurangannya dan sibuk menyalahkan dirinya sendiri, akibatnya dalam bergaul siswa jadi cenderung tidak menampilkan dirinya yang sebenarnya dan cenderung melakukan conformity, cenderung untuk menyesuaikan diri dengan keinginan atau yang ingin diperbuat oleh teman sebaya baik dalam hal pikiran, pendapat, nilai-nilai, gaya hidup, kebiasaan, keinginan dan aspek kehidupan lainnya agar ia merasa diterima oleh teman teman sebayanya. Individu yang mempunyai penerimaan diri rendah akan mudah pasrah pada nasib mengenai penilaian orang lain kepada diri sehingga menyebabkan ketidakinginan untuk mau merubah sesuatu yang buruk dalam diri (Qonita \& Dahlia, 2019). Siswa yang tidak memiliki penerimaan diri yang baik akan sangat rentan menjadi tertekan dan mengalami kesulitan dalam memusatkan konsentrasi pikiran, melamahkan motivasi 
dan daya juang siswa. Pada akhirnya siswa tidak mampu mengaktualisasikan kemampuannya dalam mengembangkan dirinya dengan baik.

Setiap individu termasuk siswa SMP Negeri 8 Makassar kelas VII sebaiknya memiliki self acceptance yang ditanamkan pada diri, namun pada kondisi yang ada di lapangan ternyata masih dijumpai siswa yang memiliki penerimaan diri rendah. Berdasarkan hasil wawancara yang dilakukan peneliti, ada 10 siswa pada kelas VII.6, yaitu 5 siswa perempuan dan 5 siswa laki-laki yang teridentifikasi memiliki penerimaan diri rendah ditandai dengan adanya rasa malu bersosialisasi dengan temannya karena merasa bahwa fisiknya kurang bagus, berasal dari keluarga yang ekonominya rendah, merasa bahwa dia bodoh dibanding temannya yang lain, kurang percaya diri tampil didepan kelas, marah jika dikritik oleh temannya dan malas mengikuti kegiatan ekstrakurikuler di sekolah. Siswa yang tidak memandang dirinya secara positif cenderung tidak mampu memahami kelebihan dan kemampuan yang ada dalam diri, sehingga perkembangan siswa akan terhambat dan akan kesulitan dalam meningkatkan kualitas dirinya Bahkan jika dibiarkan terus menerus, siswa tersebut bisa menjadi siswa yang minder, tidak menghargai diri sendiri, menyalahkan kondisi diri dan lingkungannya disertai stress dan depresi.

Sebagaimana hasil penelitian yang telah dilakukan oleh (Muawanah, 2012) bahwa terdapat beberapa kematangan emosi yang dimiliki oleh setiap remaja. Hal ini tentu sangat memiliki dampak negatif bagi perkembangan siswa. Prayitno (Azam, 2016) menjelaskan mengenai layanan bimbingan kelompok merupakan salah satu layanan Bimbingan dan konseling yang efektif sebagai kegiatan berbentuk kelompok dalam memberikan informasi, adanya penyusunan rencana dalam mengambil keputusan yang tepat untuk mencapai tujuan bimbingan dan konseling meskipun terdapat berbagai dinamika kelompok. Bimbingan kelompok lebih merupakan suatu upaya bimbingan kepada individu-individu melalui kelompok.

Menurut Mifzal yang dikutip oleh (Sitti Nurkia \& Sulkifly, 2020) alasan kenapa menggunakan layanan bimbingan kelompok adalah karena tidak dapat dipungkiri, pengaruh teman sebaya kepada seorang anak begitu tinggi. Bahkan, sering kali lebih tinggi dibandingkan dengan pengaruh kedua orang tuanya atau gurugurunya Terdapat berbagai teknik 
bimbingan kelompok seperti bermain sosiodrama dan permainan, yang dinamis dan terpusat pada pemikiran dan perilaku sadar dan melibatkan fungsi-fungsi terapi seperti sifat permisif, orientasi pada kenyataan, saling menerima dan saling mendukung. Berdasarkan dari penelitian (Agustin et al., 2020; Haolah et al., 2020; Sulistiyanti \& Fitria, 2020) bahwa teknik permainan, role playing ataupun simulasi dapat diterapkan dengan cara bimbingan kelompok.

Hal ini selaras dengan penelitian (Fitri, 2015; Noor et al., 2020; Putri, 2020) yang menyatakan bahwa bimbingan kelompok dapat dilakukan untuk meningkatkan penerimaan diri siswa. Layanan bimbingan kelompok dengan teknik permainan merupakan salah satu teknik yang sering digunakan oleh guru BK dan efektif untuk membantu siswa, antara lain lebih meningkatkan pemahaman diri, konsep diri, dan penghargaan terhadap diri, serta mampu berinteraksi dengan orang lain yang memiliki korelasi positif terhadap penerimaan diri (self-acceptance) siswa.

\section{METODE PENELITIAN}

Pendekatan yang digunakan atau dipilih dalam pelaksanaan penelitian ini adalah pendekatan kualitatif. Jenis penelitian yang digunakan adalah penelitian tindakan kelas yang bersifat deskriptif. Teknik pengumpulan data dilakukan dengan observasi, teknik analisis data secara kualitatif dan melakukan refleksi. Subjek Penelitian yaitu siswa kelas VII di SMP Negeri 8 Makassar dibulan oktober minggu ke 2-4 dan bulan november pada minggu ke 2 . Penelitian menggunakan 2 siklus yang terdiri dari komponen Perencanaaan (planning), Pelaksanaan Tindakan (acting), Pengamatan (observing), Refleksi (reflecting). Gambaran bentuk desainnya adalah:

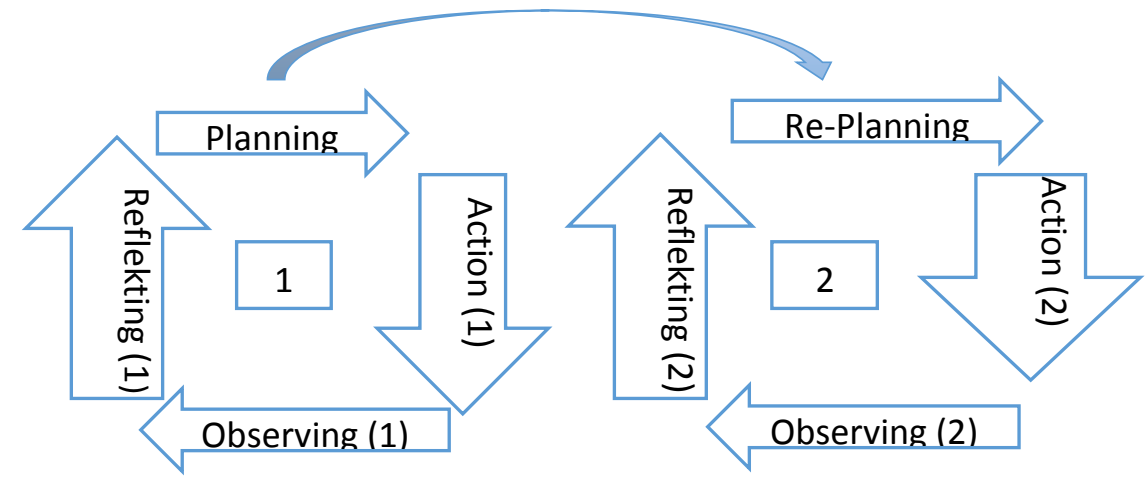

Gambar 1. Siklus Penelitian 
PEDAGOGIKA

Volume 12 (Nomor 1) 2021

HaL. 120-133

\section{HASIL DAN PEMBAHASAN}

\section{Hasil Penelitian}

Jumlah siswa kelas VII 6 sebanyak 36 orang siswa. Berdasarkan obeservasi, wawancara wali kelas dan teman kelas, ada beberapa orang siswa yang teridentifikasi memiliki penerimaan diri yang rendah. yakni 5 orang siswa laki, 5 orang siswa perempuan. Seluruh siswa ini, enggan untuk tampil didepan kelas ketika diberikan tugas presentasi. Selain itu ada 4 orang siswa yang merasa malu bersosialisasi dengan temannya karena merasa bahwa fisiknya kurang bagus, 3 orang siswa yang berasal dari keluarga yang ekonominya rendah, 3 orang siswa merasa bahwa dia bodoh dibanding temannya yang lain. Kondisi awal tingkat penerimaan diri siswa. Berdasarkan tabel dibawah sebelum di berikan teknik permainan dalam bimbingan kelompok kondisi awal siswa termasuk pada kategori rendah.

Tabel 1. Kondisi Awal Tingkat Penerimaan Diri Siswa

\begin{tabular}{ccc}
\hline Persentase & Kriteria & Responden \\
\hline $80 \%-10 \%$ & Sangat tinggi & 0 \\
$60 \%-79 \%$ & Tinggi & 0 \\
$40 \%-59 \%$ & Sedang & 3 \\
$20 \%-39 \%$ & Rendah & 7 \\
$0 \%-19 \%$ & Sangat rendah & 0 \\
\hline Jumlah & & $\mathbf{1 0}$ \\
\hline
\end{tabular}

Penelitian ini menggunakan teknik permaian untuk meningkatkan penerimaan diri siswa di SMP Negeri 8 Makassar yang dilaksanakan dalam 2 siklus, siklus pertama yaitu melalukan persiapan (planning) yang dilakukan selama 2 hari dengan cara membuat skenario, menentukan waktu pelaksanaan tindakan, menata setting bimbingan kelompok dengan teknik permainan, membuat pedoman dan lembar observasi dan menyediakan jurnal selama kegiatan berlangsung.
Kedua, melakukan pelaksanaan tindakan (acting) I yaitu membentuk kelompok (Briefing), peralihan, kegiatan (leading) sebanyak 2 kali pertemuan, pertemuan pertama melakukan permainan menulis tentang pengalaman bahagia, pengalaman sedih, sifat buruk diri, sifat yang disukai dan tidak disukai pada temandan hal positif dalam diri. Dan kegiatan yang terakhir yaitu tahap pengakhiran (Debriefing). 
PEDAGOGIKA

Volume 12 (Nomor 1) 2021

HaL. 120-133

Ketiga, pengamatan (observing) I $0-24$ : Pemberian layanan kurang baik dilaksanakan oleh konselor dan kolaborator. $\quad 25$ - 48 : Pemberian layanan cukup baik

Hasil dari pengamatan terhadap tindakan $49-72$ : Pemberian layanan baik (Total guru/konselor memiliki kriteria. Kriteria nilai tindakan ideal)

penilaian pada tindakan layanan dalam

73 - 96 : Pemberian layanan sangat baik

bimbingan kelompok dibagi menjadi 4

(empat) tingkatan kualitas yakni :

Tabel 2. Hasil Observasi Kemampuan Konselor dalam Memberikan Layanan Bimbingan Kelompok

\begin{tabular}{lccc}
\hline \multirow{2}{*}{ Tahap Bimbingan Kelompok } & \multicolumn{2}{c}{ Pelaksanaan Tindakan Siklus I } & \multirow{2}{*}{ Hasil Tindakan Ideal } \\
\cline { 2 - 3 } & BKp I & BKp II & \\
\hline Tahap Awal & 11 & 13 & 16 \\
Pembentukan & 14 & 16 & 24 \\
Peralihan & 3 & 5 & 8 \\
Kegiatan & 12 & 12 & 20 \\
Pengakhiran & 15 & 18 & 28 \\
\hline Jumlah & $\mathbf{5 5}$ & $\mathbf{6 4}$ \\
\hline Rata-rata & \multicolumn{3}{c}{$\mathbf{5 9 , 5}$} \\
\hline \multicolumn{4}{c}{ Kualitas Layanan (59,5) adalah Baik } \\
\hline
\end{tabular}

Berdasarkan tabel di atas diketahui baik dengan rata-rata skor perolehan 59,5. bahwa pelaksanaan tindakan guru/konselor Selanjutnya hasil dari pengamatan terhadap peneliti dalam layanan bimbingan kelompok tindakan siswa yakni :

teknik Permainan termasuk dalam kategori

Tabel 3. Hasil Observasi Tingkat Penerimaan Diri Siswa dalam Pelayanan Bimbingan Kelompok

\begin{tabular}{cccc}
\hline Persentase & \multirow{2}{*}{ Kriteria } & I & II \\
\cline { 3 - 4 } & & 0 & 0 \\
$60 \%-10 \%$ & Sangat tinggi & 0 & 5 \\
$40 \%-59 \%$ & Tinggi & 7 & 5 \\
$20 \%-39 \%$ & Sedang & 3 & 0 \\
$0 \%-19 \%$ & Rendah & 0 & 0 \\
\hline Jumlah & Sangat rendah & $\mathbf{1 0}$ & $\mathbf{1 0}$ \\
\hline
\end{tabular}

Berdasarkan tabel di atas diketahui siswa dalam bimbingan kelompok teknik bahwa tingkat kemampuan penerimaan diri Permainan untuk semua anggota kelompok 
yang berjumlah 10 orang siswa kondisi kualitas perolehan layanannya berada pada kategori tinggi sebanyak 5 dan pada kategori sedang sebanyak 5 siswa, sehingga untuk peningkatan kualitas berikutnya perlu kiranya diperhatikan lagi. Analisis refleksi pada Pada siklus I telah dilaksanakan bimbingan kelompok teknik permainan hasilnya dibandingkan dengan kondisi awal tingkat kemampuan penerimaan diri siswa yang terdiri dari 9 aspek dengan kategori rendah sebanyak 7 siswa dan kategori sedang sebanyak 3 siswa mengalami peningkatan pada siklus I yaitu dengan kategori sedang 5 siswa dan kategori tinggi 5 siswa. Sehingga dengan kata lain pada siklus I layanan bimbingan kelompok teknik permainan mencapai keberhasilan dengan kategori baik. Meskipun pada siklus I sudah mencapai tingkat keberhasilan atau tingkat penerimaan diri siswa sudah meningkat dan berada pada kategori Tinggi, namun konselor/ peneliti masih menyadari masih banyak hal yang perlu dibenahi sehubungan dengan peningkatan kualitas layanan yang akan diberikan.

Pada siklus kedua dilakukan dalam dua kali pertemuan dan dilaksanakan berdasarkan kesepakatan bersama anggota kelompok, kegiatan pertama yaitu perencanaan (planning) II dengan cara membuat skenario. Kedua, melakukan pelaksanaan tindakan (acting) I yaitu membentuk kelompok (Briefing), peralihan, kegiatan (leading) sebanyak 1 kali pertemuan, pertemuan pertama melakukan permainan menulis tentang pengalaman bahagia, pengalaman sedih, sifat buruk diri, sifat yang disukai dan tidak disukai pada temandan hal positif dalam diri. Dan kegiatan yang terakhir yaitu tahap pengakhiran (Debriefing). Ketiga, pengamatan (observing) II dilaksanakan oleh konselor dan kolaborator. Hasil dari pengamatan terhadap tindakan guru/konselor memiliki kriteria. Kriteria penilaian pada tindakan layanan dalam bimbingan kelompok dibagi menjadi 4 (empat) tingkatan kualitas yakni :

Ketiga, pengamatan (observing) I dilaksanakan oleh konselor dan kolaborator. Hasil dari pengamatan terhadap tindakan guru/konselor memiliki kriteria. Kriteria penilaian pada tindakan layanan dalam bimbingan kelompok dibagi menjadi 4 (empat) tingkatan kualitas yakni :

0 - 24 : Pemberian layanan kurang baik

25 - 48 : Pemberian layanan cukup baik

49 - 72 : Pemberian layanan baik (Total nilai tindakan ideal)

73 - 96 : Pemberian layanan sangat baik 
Tabel 4. Hasil Observasi Kemampuan Konselor dalam Memberikan Layanan Bimbingan Kelompok

\begin{tabular}{lccc}
\hline \multirow{2}{*}{ Tahap Bimbingan Kelompok } & \multicolumn{2}{c}{ Pelaksanaan Tindakan Siklus II } & \multirow{2}{*}{ Hasil Tindakan Ideal } \\
\cline { 2 - 3 } & BKp III & BKp IV & 16 \\
Tahap Awal & 15 & 15 & 24 \\
Pembentukan & 20 & 21 & 8 \\
Peralihan & 6 & 7 & 20 \\
Kegiatan & 15 & 15 & 28 \\
Pengakhiran & 23 & 25 & 96 \\
\hline Jumlah & 79 & 83 & \\
\cline { 1 - 2 } Rata-rata & \multicolumn{3}{c}{81} \\
\hline \multicolumn{4}{c}{ Kualitas Layanan (81) adalah Sangat Baik } \\
\hline
\end{tabular}

Berdasarkan tabel di atas diketahui rata-rata skor perolehan 81. Jadi layanan bahwa pelaksanaan tindakan guru/konselor bimbingan kelompok pada siklus ke II sudah peneliti dalam layanan bimbingan kelompok berhasil. Selanjutnya hasil dari pengamatan dengan menggunakan teknik permainan terhadap tindakan siswa yakni : termasuk dalam kategori sangat baik dengan

Tabel 5. Hasil Observasi Tingkat Penerimaan Diri Siswa dalam Pelayanan Bimbingan Kelompok

\begin{tabular}{cccc}
\hline \multirow{2}{*}{ Persentase } & \multirow{2}{*}{ Kriteria } & III & Pertemuan \\
\cline { 3 - 4 } & Sangat tinggi & 2 & 5 \\
$60 \%-10 \%$ & Tinggi & 6 & 5 \\
$40 \%-79 \%$ & Sedang & 2 & 0 \\
$20 \%-39 \%$ & Rendah & 0 & 0 \\
$0 \%-19 \%$ & Sangat rendah & 0 & 0 \\
\hline Jumlah & & $\mathbf{1 0}$ & $\mathbf{1 0}$ \\
\hline
\end{tabular}

Berdasarkan tabel hasil observasi di atas dapat diketahui, bahwa respon siswa atau kondisi siswa dalam layanan bimbingan kelompok dengan menggunakan teknik Permainan pada umumnya berada pada kategori sangat Tinggi sebanyak 5 siswa dan pada kategori tinggi sebanyak 5 pada siklus ke II. Berdasarkan hasil yang diperoleh maka setiap pertemuan partisipasi siswa mengalami peningkatan dan memberikan bukti bahwa kegiatan yang dilaksanakan dapat diikuti dengan baik oleh para siswa. Analisis data dan refleksi dari hasil observasi penelitian kondisi awal terjadi peningkatan pada siklus II. Sehingga dengan kata lain pada siklus II layanan bimbingan kelompok teknik 
permainan mencapai keberhasilan dengan kategori sangat tinggi. Jadi tingkat keberhasilan di siklus II sudah menunjukkan bahwa kegiatan bimbingan kelompok dengan teknik permainan dapat membantu meningkatkan penerimaan diri siswa.

\section{Pembahasan}

Berdasarkan pelaksanaan tindakan yang telah dilakukan, Penerapan Layanan Bimbingan Kelompok dengan Teknik Permainan Untuk Meningkatkan Penerimaan Diri siswa Kelas VII di SMP Negeri 8 Makassar telah menunjukkan perubahan terhadap peningkatan penerimaan diri siswa yang ditandai dengan meningkatnya 9 aspek yang menjadi ukuran dalam tingkat penerimaan diri siswa yaitu mendengarkan dengan seksama apa yang sedang dijelaskan oleh pemimpin kelompok, mau menerima pendapat orang lain, mengemukakan pendapat/gagasan/ide, bertanya jika ada hal yang tidak dimengerti, melakukan permainan sesuai instruksi, dapat mengatur keadaan emosi, mampu bekerjasama dengan anggota kelompok, meneriman kritikan tanpa memusuhi serta mengemukakan manfaat permainan, pada saat proses bimbingan berlangsung melalui pengamatan langsung terhadap aktivitas keseharian siswa selama peneliti melakukan penelitian dimana dalam kesehariannya kebiasaan siswa tidak pernah menyatakan pendapat, tidak mau menerima pendapat orang lain, tidak mau bertanya, marah ketikan dikritik, emosi tidak stabil, kurang mampu bekerjasama dan bersosialisasi serta malu tampil didepan sudah jarang ditemukan. Selain itu perubahan yang terjadi dapat pula dilihat pada hasil persentase observasi tingkat keberhasilan kegiatan bimbingan kelompok dengan menggunakan teknik permainan.

Penerimaan diri memiliki posisi yang penting dalam pembentukan kepribadian yang sehat (Resty, 2016), penerimaan diri merupakan pondasi dalam membangun kesehatan dalam menghargai diri. Sejalan dengan pendapat tersebut, dengan demikian dapat dipahami bahwa Penerimaan diri merupakan unsur penting yang perlu dimiliki untuk membentuk kondisi jiwa dan kepribadian yang baik dan ketiadaannya dapat memberikan pengaruh pada kurang berkembangnya kepribadian yang diharapkan. Dalam pelaksanaan bimbingan kelompok banyak teknik atau strategi yang dapat digunakan terutama dalam meningkatkan penerimaan diri. Peneliti 
mencoba menerapkan salah satu alternatif teknik yang dapat digunakan yaitu teknik permainan. Menurut Geldard, K., \& Geldard (2012), menyatakan bahwa permainan dapat membantu perkembangan individu baik secara fisik, kognitif, emosional dan sosial sehingga individu memperoleh pengalaman dan ekspresi natural yang dimilikinya dapat terlihat. Tetapi situasi itu hampir selalu dimodifikasi, apakah dibuat lebih sederhana, atau diambil sebagian, atau dikeluarkan dari konteksnya. Dalam hal ini perlu diperhatikan bahwa situasi yang disimulasikan hendaknya tidak terlalu kompleks dan tidak terlalu sederhana. Apabila terlalu kompleks para pemain menjadi kurang berani memainkannya, sebaliknya apabila terlalu mudah mereka akan cepat bosan. Meskipun demikian, permainan simulasi tetap dapat menyediakan suatu gambaran kehidupan dan kenyataan yang berarti.

Melalui Penerapan Teknik permainan dalam bimbingan kelompok diharapkan siswa yang memiliki penerimaan diri rendah dapat diarahkan agar bisa meningkatkan penerimaan dirinya menjadi lebih baik. Dengan menggunakan teknik permaian yakni permainan menggambar jari dan menyusun kata. Pada permainan menggambar jari, siswa diharapkan untuk mampu memiliki gambaran yang positif terhadap dirinya dengan memahami dan menyadari bahwa setiap individu punya kelebihan dan kekurangan yang mesti mereka kelolah dengan baik dan serta tidak malu untuk menampilkan dirinya apa adanya. Selain itu, permainan juga melatih siswa agar mampu mengelolah kritik yang diterimanya, serta mampu berinteraksi dengan orang lain dengan baik. Permainan kedua adalah permainan menyusun kata. Melalui permainan ini, siswa diharapkan mampu bekerjasama dengan orang lain, dapat bertoleransi dan mengatur rasa kemarahannya, tidak memusuhi orang lain ketika dikritik, dan mampu mngatur keadaan emosinya. Selain kemampuan khusus yang diharapkan dimiliki oleh siswa melalui permainan yang dilakukan, siswa juga diharapkan mampu memilki kemampuan umum yang diharapkan didapatkannya melalui kegiatan kelompok seperti, mau menerima pendapat orang lain, mampu berpendapat atau mengemukakan ide/gagasan, bertanya jika ada hal yang tidak dimengerti serta mampu menyampaikan makna dan manfaat atas setiap kegiatan yang dilakukan.

\section{Pedagogika.fip@ung.ac.idＰ-ISSN: 2086-4469 E-ISSN: 2716-0580}


Tingkat penerimaan diri siswa dengan teknik permainan dalam bimbingan kelompok dapat di tingkatkan, hal ini sejalan dengan kondisi yang telah ditemukan di lapangan yakni dari 9 aspek yang diteliti seperti mendengarkan dengan seksama apa yang sedang dijelaskan oleh pemimpin kelompok, mau menerima pendapat orang lain, mengemukakan pendapat/gagasan/ide, bertanya jika ada hal yang tidak dimengerti, melakukan permainan sesuai instruksi, dapat mengatur keadaan emosi, mampu bekerjasama dengan anggota kelompok, meneriman kritikan tanpa memusuhi serta mengemukakan manfaat permainan. Diperoleh hasil bahwasanya setiap kali peneliti bersama mitra kolaborator melakukan observasi ditemukan adanya perubahan tingkat penerimaan diri. Yakni pada kondisi awal ditemukan pada umumnya tingkat penerimaan diri siswa rendah dan sedang, kemudian diberikan bimbingan kelompok dengan teknik permainan pada siklus I tingkat penerimaan diri yang terdiri dari 9 aspek dengan kategori tinggi sebanyak 5 siswa dan kategori sedang sebanyak 5 siswa dan pada siklus II meningkat menjadi 5 siswa berada pada kategori sangat tinggi dan 5 siswa berada pada kategori tinggi. Siklus 1 dengan dua kali pertemuan mengalami peningkatan dengan kategori tinggi namun masih perlu diadakan perbaikan dalam layanan sehingga di adakan siklus II dan pada siklus II juga terjadi peningkatan yang sangat tinggi

Berdasarkan pemaparan tersebut, maka indicator kinerja dalam penelitian ini sudah tercapai dengan melaksanakan dua siklus dengan empat kali pertemuan. Namun demikian setalah penelitian ini, konselor masih perlu memberikan penguatan kepada siswa agar tingkat penerimaan diri siswa lebih di tingkatkan lagi dalam pencapaian hasil belajar atau prestasi belajar yang optimal.

Ketidakmampuan individu dalam mengelola kesenjangan diri menunjukkan rendahnya penerimaan diri. Individu yang mempunyai penerimaan diri rendah akan mudah putus asa, selalu menyalahkan dirinya, malu, rendah diri akan keadaannya, merasa tidak berarti, merasa iri terhadap keadaan orang lain, akan sulit membangun hubungan positif dengan orang lain, dan tidak bahagia.

\section{SIMPULAN}

Layanan bimbingan kelompok dengan menggunakan teknik permainan dapat membantu meningkatkan penerimaan diri yakni dari 9 aspek penerimaan diri dari 
kondisi awal terus meningkat pada siklus 1 dan siklus 2 yakni dari kondisi awal dengan jumlah siswa 10 dengan berada pada kategori rendah 3 dan pada kategori sedang 7 siswa dan terjadi perubahan pada siklus 1 dengan kategori tinggi sebanyak 5 siswa dan kategori sedang sebanyak 5 siswa dan dilakukan siklus ke II karena masih perlu peningkatan dalam bentuk layanan yang belum maksimal sehingga pada siklus II terjadi peningkatan 5 siswa berada pada kategori sangat tinggi dan 5 siswa berada pada kategori tinggi. Teknik permainan dalam bimbingan kelompok yang digunakan dapat diterima untuk meningkatkan penerimaan diri siswa kelas VII di SMP Negeri 8 Makassar.

\section{REFERENSI}

Agustin, D., Sumarwiyah, S., \& Sucipto, S. (2020). Peningkatan Sikap Optimisme Anak Panti Asuhan Melalui Layanan Bimbingan Kelompok dengan Teknik Simulasi. Jurnal Prakarsa Paedagogia, $3(1)$.

Azam, U. (2016). Bimbingan dan Konseling Perkembangan Disekolah. Yogyakarta: Grup penerbitan CV Budi Utama.

Fitri, L. (2015). Efektivitas Teknik Permainan untuk Meningkatkan Penerimaan Diri Siswa. Edusentris, 2(2), 156-165.

Geldard, K., \& Geldard, D. (2012). Konseling
Anak-Anak Sebuah Pengantar Praktis. Indeks.

Haolah, S., Rohaeti, E. E., \& Rosita, T. (2020). Penerapan Bimbingan Kelompok Teknik Role Playing untuk Meningkatkan Kematangan Karier. FOKUS (Kajian Bimbingan \& Konseling Dalam Pendidikan), 3(1), 18.

Hasmalawati, N. (2018). Pengaruh Citra Tubuh dan Perilaku Makan Terhadap Penerimaan Diri pada Wanita. Psikoislamedia: Jurnal Psikologi, 2(2), 107-115.

Hoffman, Louis, Lopez, Abraham, J, \& Moats, Michael, E, Bernard, M. (2013). The Strength of Self Acceptance Theory, Practice and Research (E. Bernard, Michael (ed.)). New York: SpringerVerlag. https://doi.org/10.1007/978-14614-6806-6

Hurlock, E. (2013). Psikologi Perkembangan Anak. Jakarta: Erlangga.

Mualifah, A., Barida, M., \& Farhana, Lady. (2019). The Effect of Self-Acceptance and Social Adjustment onSenior High School Students' Self-Concept. International Journal of Educational Research Review, 4, 719-724.

Muawanah, L. B. (2012). Kematangan emosi, konsep diri dan kenakalan remaja. Persona: Jurnal Psikologi Indonesia, 1(1).

Nurkia, S., \& Sulkifly. (2020). Penerapan Bimbingan Kelompok dengan Teknik Modeling Simbolis untuk Meningkatkan 
Motivasi Belajar Siswa . JAMBURA Guidance and Counseling Journal, 1(2), 56-65. https://doi.org/10.37411/jgcj.v1i2.521

Noor, M., Atieka, N., \& Yunisa, I. (2020). Pengaruh Layanan Bimbingan Kelompok terhadap Penerimaan Diri pada Remaja di Desa Mataram Baru Sukadana Lampung Timur. Counseling Milenial (CM), 1(2), 130-142.

Putri, D. A. S. (2020). Pengembangan Modul Bimbingan ke Arah Penerimaan Diri Melalui Bimbingan Kelompok Siswa SMKN Tutur Pasuruan. Jurnal Bimbingan Dan Konseling Borneo, 2(1).

Qonita, R., \& Dahlia, D. (2019). Hubungan Penerimaan Diri Dengan Harga Diri pada Pengemis di Kota Banda Aceh. Seurune Jurnal Psikologi Unsyiah, 2(1), 33-49.

Resty, G. T. (2016). Pengaruh Penerimaan Diri Terhadap Harga Diri Remaja di Panti Asuhan Yatim Putri Aisyayah Yogyakarta. Jurnal Riset Mahasiswa Bimbingan Dan Konseling, 5(1).

Saifuddin, S. (2021). Penerapan Teknik Role Playing untuk Meningkatkan Penerimaan Diri Siswa di SMK Negeri 1 Makassar. DISHUM: DDI Islamic Studies and Humanities Research, 1(1), 64-75.

Sekali, R. B. R. K. (2020). Upaya Meningkatkan Penerimaan Diri (Self Acceptance) Siswa Melalui Konseling Individu dengan Pendekatan Realita Kelas XI SMA Negeri 15 Bandar Lampung. Jurnal Evaluasi Dan
Pembelajaran, 2(2), 135-147.

Sitorus, M. W., Badrujaman, A., \& Fitri, S. (2019). Pengaruh layanan bimbingan kelompok dengan metode permainan terhadap penerimaan diri siswa. ENLIGHTEN: Jurnal Bimbingan Konseling Islam, 2(1), 18-23.

Sulistiyanti, D., \& Fitria, E. (2020). Pengaruh Layanan Bimbingan Kelompok Teknik Permainan Simulasi Kartu Uno Terhadap Eksplorasi Karir. PD ABKIN JATIM Open Journal System, 1(2), 2949. 